Васиљ Јововић

Универзитет Црне Горе

Филозофски факултет Никшић vasilj@ac.me
Оригиналан научни рад

примљено: 24. април 2014

прихваћено: 1. октобар 2014

\title{
СРЕДЊОВЈЕКОВНИ МАНАСТИРИ У СКАДАРСКОМ БАСЕНУ У ПЕРИОДИЦИ НА ПРОСТОРУ ЦРНЕ ГОРЕ ОД 1835. ДО 1941. ГОДИНЕ
}

Сажетак: У овом раду обрађени су текстови у периодици на простору Црне Горе од 1835. до 1941. године у којима су описани манастири у Скадарском басену. Скадарско језеро са околином током средњег вијека географски је припадало Дукљи, Зети и било у саставу државних творевина које су током свог трајања оставиле богату културну заоставштину. Српске владарске династије Војислављевићи, Немањићи, Балшићи и Црнојевићи подизали су и богато обдаривали манастире у Скадарском басену: Пречисту крајинску, Врањину, Бешку, Старчево, Морачник, Ком. О тим манастирима у црногорској периодици писали су: Филип Радичевић, Иларион Руварац, Андрија Јовићевић, Марко Драговић, Лазар Томановић, Тома Ораовац и др.

Кључне ријечи: Скадарски басен, манастири, периодика, повеље, Црна Гора.

Архимандрит Нићифор Дучић у својој књизи Књижевни радови опомиње млађи нараштај и учена српска друштва да се проучи и опише српска Зета, као славна и знаменита српска област. Филип Радичевић наглашава да је простор Скадарског језера због великог броја манастира и њихових калуђера који су проводили вријеме у молитви и посту назван „српском Светом Гором“. ${ }^{1}$ Иларион Руварац наводи ко је све писао о манастирима у Скадарском басену: владика Василије Петровић, Маријан Болица, Поп Дукљанин. ${ }^{2}$

У црногорској периодици од 1835. до 1941. године велики је број текстова стручног и публицистичког карактера у којима су описани манастири на Скадарском језеру: манастир Врањина, ${ }^{3}$ манастир Пречиста крајинска, ${ }^{4}$ манастир Ком, ${ }^{5}$ манастир

\footnotetext{
${ }^{1}$ Ф. Радичевић, О Врањинском манастиру, Просвјета, I/1893, св. III, 98.

${ }^{2}$ И. Руварац, Српски манастири у скадарском блату, Камичци-прилошци за други зетски дом, Просвјета, II/1894, св. VIII, 421-422.

${ }^{3}$ Ф. Радичевић, О Врањинском манастиру; И. Руварац, Манастир св. Николе на Врањини у скадарском блату, Камичци - прилошци за други зетски дом, Просвјета, II/1894, св. X, 530-540; св. XII, 646-656; Андрија Јовићевић, Манастир Врањина, Древни српски манастири, Никшић 2011, 27-32 (= Зетски
} 
Бешка, ${ }^{6}$ манастир Старчево, ${ }^{7}$ манастир Морачник. ${ }^{8}$

Манастири у Скадарском басену су подизани као задужбине српских средњовјековних владара: Војислављевића, Немањића, Балшића, Црнојевића, високих црквених достојанственика, који су их богато даривали и издавали им повеље. За манастир Св. Николе на Врањини каже се да га је подигао зетски епископ Иларион почетком XIII вијека. ${ }^{9}$ Иларион Руварац критикује мишљења Константина Јиречека, који сматра да је манастир основао архиепископ Сава I Немањић, ${ }^{10}$ и П. А. Ровинског, који каже да је манастир основао архиепископ Сава II. ${ }^{11}$ Руварац сматра да је први српски архиепископ Сава Немањић поставио Илариона за зетског епископа око 1222/23. године. ${ }^{12}$ Андрија Јовићевић наводи да је темељ манастиру Св. Николе на Врањини поставио први зетски епископ Иларион око 1233. године. ${ }^{13}$ За манастир Пречиста крајинска истиче се да га је подигао зетски кнез Јован Владимир. ${ }^{14}$ Цркву манастира Ком посвећену Успењу Пресвете Богородице подигао је Стефан Црнојевић док му је сједиште било на Жабљаку, ${ }^{15}$ средином XV вијека, а то мишљење потврђује грамата Ивана Црнојевића у којој се каже: „Све што су имале цркве Комска и Горица, које су обје цркве саградили наши родитељи... “16 Манастир Бешка горица подигла је Јелена Балшић, кћи кнеза Лазара Хребељановића, а мајка Балше III 1440. године, и посветила га је Св. Богородици. ${ }^{17}$ За манастир Старчева горица се истиче да га је основао старац Макарије у вријеме Ђурађа I Балшића ${ }^{18}$ и да манастир и црква на Старчевој горици 1440. године нијесу били пусти, већ се у њима држала служба. ${ }^{19}$

Манастири на Скадарском језеру су богато даривани од стране владара. Манастир Св. Николе на Врањини даривали су: Сава Немањић, краљ Стефан Владислав, краљ Стефан Урош (о. 1255), краљица Јелена (о. 1280), краљ Милутин

гласник, V/1933, бр. 64, 2; бр. 65, 2; бр. 66, 2); И., Манастир св. Николе на Врањини, Зетски гласник, 11/1939, бр. 783, 2; бр. 784, 2; Марко Драговић, С пута, Глас Црногорца, XVI/1887, бр. 28, 2 ; Л. Томановић, Излет на Врағинску славу, Нова Зета, I/1889, 175-183.

${ }^{4}$ Андрија Јовићевић, Манастирске рушевине на Скадарском језеру, Зетски гласник, VII/1935, бр. $52,3$.

${ }^{5}$ Ф. Радичевић, Успенски манастир на Кому, Просвјета, I/1893, св. VI, 209-210; И. Руварац, Српски манастири у скадарском блату, св. VIII, 421-425; Андрија Јовићевић, Нешто о манастиру Кому, Глас Црногорца, XXVII, бр. 38, 2; Андрија Јовићевић, Манастир Ком, Древни српски манастири, Никшић 2011, 90-92 (= Зетски гласник, V/1933, бр. 73, 4; бр. 76, 5).

${ }^{6}$ И. Руварац, Бешка-Горица, Камичци - прилошци за други зетски дом, Просвјета, II/1894, св. IX, 475-478; Андрија Јовићевић, Манастирске рушевине на Скадарском језеру, Зетски гласник, VII/1935, бр. 52,3 .

${ }^{7}$ И. Руварац, Старчева Горица, Камичци - прилошци за други зетски дом, Просвјета, II/1894, св. IX, 478.

${ }^{8}$ И. Руварац, Морачник, Камичци - прилошци за други зетски дом, Просвјета, II/1894, св. IX, 479.

${ }^{9}$ И. Руварац, Манастир св. Николе на Вранини у скадарском блату, св. Х, 536; И., Манастир св. Николе на Врањини, бр. 783, 2; А. Јовићевић, Манастир Врањина, 27.

${ }^{10}$ И. Руварац, Манастир св. Николе на Врањини у скадарском блату, св. Х, 537-538.

${ }^{11}$ Исто, св. Х, 538.

${ }^{12}$ Исто, св. ХІІ, 646.

${ }^{13}$ А. Јовићевић, Манастир Врањина, 27.

${ }^{14}$ А. Јовићевић, Манастирске рушевине на Скадарском језеру, 3.

${ }^{15}$ Ф. Радичевић, Успенски манастир на Кому, 209.

${ }^{16}$ А. Јовићевић, Манастир Ком, 90.

${ }^{17}$ А. Јовићевић, Манастирске рушевине на Скадарском језеру, 3.

${ }^{18}$ И. Руварац, Старчева Горица, св. IX, 478.

${ }^{19}$ Исто, 479. 
(о. 1296), краљ Стефан Дечански (о. 1326), цар Душан, Ђурађ Страцимировић (1404), Балша III (1417. и 1420), матагушка властела (1468), Иван Црнојевић (1469), турски султан $1478 .^{20}$ Сава Немањић је дао земљу метоха Св. Спаса на Плавници манастиру на Врањини, као и повластице, да не даје работнике властели, ослобађа га од рада на путевима, од војске, од зидања градова, да епископ има право да се назива архиепископом, да калуђери бирају игумана и да га потврђује епископ. ${ }^{21}$ Краљ Владислав даровао му је осим села Годиња и црмничка села Медвеђу Главу и Крушевицу; краљица Јелена осим села Крњице даровала му је око 1280. године Уљаник у Крушевицама; краљ Милутин даровао му је осим Орахова, око 1296. године, од трга Светог Срђа по 100 перпера годишње, потврђујући хрисовуље својих предака Саве. $^{22}$ Краљ Милутин приложио је село Лимљане, Стефан Дечански Орахово и Брчели, Стефан Душан Трново, Ђурађ Страцимировић Балшић приложио je 1403/4. године половину села Раке, а Балша III 1420. године село Каруче. ${ }^{23}$ Матагужани су 1468. године приложили манастиру село Увич у Зети, земљу Јеч међу ријеком Плавницом и потоком Октабежом и до брда Михлија, а за то су им иступљена три гроба унутра у манастиру. ${ }^{24}$ Године 1469 . Иван Црнојевић издао је грамату којом је исправио све неправде учињене манастиру којом је сва приложена добра довео у старе границе и у којој се наводе границе села у Зети, Лимљанима, Лимском пољу, Брчелима, Опточићима, Томићима и Шишовићима. ${ }^{25}$ Турски султан је 1478. године да би за себе придобио људе Ивана Црнојевића, у табору испод Скадра потврдио манастиру Врањина све раније повластице. ${ }^{26}$

Манастири нијесу само проширивали своје метохе и увећавали своје приходе већ су и сами прилагани другим манастирима или су морали да дају дио својих прихода другим манастирима. Цар Душан је 29. априла 1348. године даровао манастир Врањину српском манастиру Св. Арханђела у Јерусалиму. ${ }^{27}$ Иларион Руварац опширно анализира даривање половине дохотка манастира Св. Николе на Врањини од стране српског цара Душана манастиру Св. Арханђела у Јерусалиму 1348. године, ${ }^{28}$ наводећи мишљење Н. Дучића да се манастир тог намета ослободио 1479. године, али да је одмах потпао под друго, турско господство. ${ }^{29}$ Андрија Јовићевић истиче да је цар Душан манастиру Врањини одузео право да сам себи бира игумане, већ је то радио игуман Св. Арханђела у Јерусалиму. ${ }^{30}$ Када је 1485. године подигао манастир на Цетињу, Иван Црнојевић је све имање манастира Кома приложио Цетињском манастиру. ${ }^{31}$ У хрисовуљи краља Милутина наводи се да је

\footnotetext{
${ }^{20}$ И., Манастир св. Николе на Вранини, бр. 783, 2.

${ }^{21}$ А. Јовићевић, Манастир Врањина, 27.

${ }^{22}$ Исто, 27-28.

${ }^{23}$ И. Руварац, Манастир св. Николе на Врањини у скадарском блату, св. XII, 647.

${ }^{24}$ А. Јовићевић, Манастир Врањина, 28.

${ }^{25}$ Исто.

${ }^{26}$ И., Манастир св. Николе на Врањини, бр. 784, 2.

${ }^{27}$ И., Манастир св. Николе на Врањини, бр. 783, 2.

${ }^{28}$ И. Руварац, Манастир св. Николе на Врањини у скадарском блату, св. XII, 647-648.

${ }^{29}$ Исто, 650-651.

${ }^{30}$ А. Јовићевић, Манастир Врањина, 28.

${ }^{31}$ А. Јовићевић, Манастир Ком, 92.
} 
село Брчели уступљено властелину Митру Казанцу који је подигао себи гроб у манастиру Врањина. ${ }^{32}$

Поједини манастири били су црквена средишта и у њима су се дешавали важни политички догађаји. У Врањинском манастиру била је смјештена Зетска митрополија која се из манастира Пречиста крајинска преселила у Врањину, па послије на Обод, а 1484. године на Цетиње. ${ }^{33}$ У манастиру Врањини 6. септембра 1455. године састали су се у присуству Јована Болинија, млетачког провидура за Албанију, и великог војводе Стефана Црнојевића, представници српских и арбанашких брдских племена, нарочито Хоти, Матагужи, Кучи, Пипери, Лужани, Бјелопавлићи, Никшићи и други, и заклели се на вјерност Млетачкој републици. ${ }^{34}$ Иларион Руварац је писао о игуманима Врањинског манастира ${ }^{35}$ наводећи имена игумана из XV вијека: Романа (до 1436), Никодима (о. 1454), Никандра (после 1454, а прије 1468) и Јосифа (о. 1468). ${ }^{36}$

Неки манастири били су маузолеји чланова владарских породица и високих црквених достојанственика. У манастиру Св. Николе на Врањини налази се гробница епископа Илариона. ${ }^{37}$ У манастиру Старчева горица сахрањен је штампар Божидар Вуковић. ${ }^{38}$ У манастиру Ком налазе се четири гробнице, једна Стефана Црнојевића (умро 1471), друга госпође Маре, обје гробнице су са натписима, а између њих се налазе двије гробнице без натписа. ${ }^{39}$ Архимандрит Дучић је нетачно превео натпис са гробнице Стефана Црнојевића, на шта је указао Љубомир Ковачевић 1885. године, који је тачно превео натпис и по томе је испод плоче сахрањен Љеш Црнојевић, војвода српског деспота Стефана Лазаревића, а не Стефан Црнојевић. ${ }^{40}$ Руварац је мишљења да је Љеш Црнојевић (Ђурашевић), који је умро на крају 1422. године, сахрањен у Цркви Успења Пресвете Богородице на Кому, коју је он саградио заједно са братом Ђорђем, оцем Стефана Ђурашина и Којчина Црнојевића, тако би манастир на Кому била задужбина Љеша (Алексе) и Ђорђа Црнојевића, а не сина Ђорђева Стефана. ${ }^{41}$ За гробове који се налазе у манастирској цркви Андрија Јовићевић каже да су Љеша Црнојевића и Маре, жене Стефана Црнојевића, сестре Скендер-бега, а да је у једном од преостала два гроба сахрањен Стефан Црнојевић. ${ }^{42}$

Манастири у Скадарском басену описивани су и у оквиру путописа. ${ }^{43}$ Томановић цитира Нићифора Дучића који каже да је манастир Врањина за 250

\footnotetext{
${ }^{32}$ А. Јовићевић, Манастир Врањина, 27-28.

33 Ф. Радичевић, О Врағинском манастиру, 97; А. Јовићевић, Манастирске рушевине на Скадарском језеру, 3; А. Јовићевић, Манастир Врањина, 29.

${ }^{34}$ И., Манастир св. Николе на Врањини, Зетски гласник, бр. 784, 2.

${ }_{35}^{35}$ И. Руварац, Манастир св. Николе на Вранини у скадарском блату, св. XII, 651-656.

${ }^{36}$ Исто, 656.

${ }^{37}$ И., Манастир св. Николе на Врањини, бр. 783, 2; А. Јовићевић, Манастир Врањина, 29.

${ }^{38}$ И. Руварац, Старчева Горица, св. IX, 478.

${ }^{39}$ Ф. Радичевић, Успенски манастир на Кому, 210.

${ }^{40}$ И. Руварац, Српски манастири у скадарском блату, св. VIII, 423.

${ }^{41}$ Исто, 424.

${ }^{42}$ А. Јовићевић, Манастир Ком, 91.

${ }^{43}$ Марко Драговић, С пута, Глас Црногорца, XVI/1887, бр. 28, 2; ЛазарТомановић, Излет на Врањинску славу, Нова Зета, I/1889, бр. 1,175-183.
} 
година од свог постанка био „српска Лавра и српска Митрополија, и српска народна школа, и српска сиротињска кућа, у којему је околни православни народ вазда налазио душевне и тјелесне хране.““4 Томо Ораовац такође наглашава да су све српске династије од Немањића до Црнојевића Врањини поклањале особиту пажњу и да то показује колики је значај био митрополије пренесене на Цетиње. ${ }^{45}$

У периодици на простору Црне Горе писано је и о повељама издатим манастирима у Скадарском басену. Највише је писано о повељама Врањинског манастира. Лазар Томановић наглашава да се хрисовуље издате Врањинском манастиру по Миклошићу, Јастребову и Дучићу налазе у ризници Цетињског манастира или Министарства финансија. ${ }^{46}$ Иларион Руварац наводи да се у Зборнику српских споменика који је издао Ф. Миклошић 1858 . године у Бечу налази повеља архиепископа Саве Немањића, првог српског архиепископа, од године 1233. којом се манастир Св. Николе на Врањини изузима испод власти зетског владике и повеља цара Стефана Душана од 1348. године којом се манастир Врањина подвргава српској Цркви Св. Михаила и Гаврила у Јерусалиму. ${ }^{47}$ Руварац упућује критике на рачун цара Душана и првог српског патријарха Јоаникија због прилагања манастира Врањине српској Цркви Св. Михаила и Гаврила у Јерусалиму. ${ }^{48}$ Такође, Руварац сумња у аутентичност преписа хрисовуље цара Душана који се чува у царској дворској архиви у Бечу, а која је објављена у Миклошићевом зборнику, замјерајући преписивачу да није стављао уобичајену терминологију која се користила у то вријеме. $^{49}$ О Врањинским повељама: повељи Св. Саве, краља Владислава, краља Стефана Дечанског, писао је детаљно Руварац, утврђивао њихову аутентичност, наглашавајући да су врањинске листине све сами преписи, а не оригинали, и да о њима говори по Дучићу, Јастребову и Ровинском који су те листине видјели и разгледали. ${ }^{50}$ Руварац наводи архимандрита Нићифора Дучића који каже да је Врањински манастир био подложан српској цркви у Јерусалиму од 1348. до 1479. године. $^{51}$

Филип Радичевић објавио је у Просвјети у поглављу Старине Повељу краља Стефана Владислава којом он дарива неке земље манастиру Врањини. Радичевић је Повељу нашао 1862. године у подруму (болти) Цетињске митрополије и предао је у манастирску ризницу. Радичевић даје опис повеље, писане на зечјој кожи у дужини 42, а ширини 24 центиметра, писане славеносрпским језиком и датира је истичући да је стара 648 година. ${ }^{52}$

\footnotetext{
44 Л. Томановић, Излет на Врањинску славу, 181; Томо Ораовац, Имовина Цетињског манастира, Иван бегово завештање, Зетски гласник, 8/1936, бр. 33, 2.

${ }^{45}$ Т. Ораовац, Имовина Цетињског манастира, Иван бегово завештање, 2.

${ }^{46}$ Л. Томановић, Излет на Вранинску славу, 179.

${ }^{47}$ И. Руварац, Манастир св. Николе на Вранини у скадарском блату, св. Х, 530-540.

${ }^{48}$ И. Руварац, Манастир св. Николе на Вранини у скадарском блату, 2/1893, св. XI, 531-533; св. XII, 647-648.

${ }^{49}$ И. Руварац, Манастир св. Николе на Врањини у скадарском блату, св. Х, 534.

${ }^{50}$ И. Руварац, Камичиุи - прилошичи за други зетски дом, 2/1893, св. ХІІ, 645-647.

${ }^{51}$ Исто, 650.

${ }_{52}$ Филип Радичевић, Стефан Владислав дарива неке земље манастиру Врањини, Просвјета, 2/1890, св. XI-XII, 319-320.
} 
У Гласнику Народног универзитета објављена је Повеља српске краљице Јелене којом утврђује међе и повластице села Затора. ${ }^{53}$ Иста повеља објављена је и у записима. $^{54}$

Повељу Ђурђа Страцимировића којом Врањинском манастиру прилаже половину села Раке објавио је Филип Радичевић у Просвјети. Радичевић датира Повељу у 1394. годину. ${ }^{55}$ О овој повељи Ђурађа Страцимировића Балшића Врањинском манастиру писао је и Иларион Руварац. ${ }^{56}$

Иларион Руварац наводи да за манастир Морачник на острву истог имена у Скадарском језеру има само један писмени споменик, Повеља Балше III од 25. јуна 6925, тј. 1417. године, којом он прилаже манастиру Морачнику једно гувно соли. ${ }^{57}$

У оквиру текстова о средњовјековним манастирима обрађени су стари натписи и записи.

O натпису који се сачувао на вратима манастира Бешка горица, који се налази на једном од острва Скадарског језера, између Старчева и Морачника, писао је Иларион Руварац у Просвјети ${ }^{58}$ Руварац износи тумачење И. С. Јастребова, који наводи текст натписа у коме пише да је Храм Пресвете Богородице саградила госпођа Јела, кћерка светог кнеза Лазара и жена господина Ђурђа Страцимировића, године 6948 (1440), МССССIIII (1404) и критикује мишљење Чедомиља Мијатовића да је ријеч о 1434. години. ${ }^{59}$ Послије опширне анализе текста натписа Руварац закључује да је 1440. године сазидана црква, а 1443. године стављена плоча са натписом те године урезаним од мајстора латинске вјере. ${ }^{60}$

Иларион Руварац доноси натпис са гробнице зетског епископа Илариона, сахрањеног у својој задужбини Врањинском манастиру у припрати, у којем се наводи да је ту сахрањен епископ зетски Иларион, градитељ овог светог мјеста. ${ }^{61}$

Натписе Успенског манастира на Кому доноси Ф. Радичевић. Натписи се налазе на двијема гробницама, од четири, колико их се налази у овој задужбини Црнојевића. ${ }^{62}$

У приватним рукама у Одеси, налази се једно јеванђеље са записом на њему да је јеромонах манастира Врањине приложио манастиру јеванђеље у доба деспота Ђурђа 1436. године. ${ }^{63}$

О манастиру на острву Старчева горица И. Руварац наводи да има неколико записа. У Српско-далматинском магазину за 1864. годину на стр. 174 помиње се

\footnotetext{
${ }^{53}$ Повеља, којом српска краљииа Јелена утврђује међе и повластице сеча Затора (између 1278-1308), Гласник Народног универзитета Боке Которске, II/1935, бр. 1-3. 17.

${ }_{54}$ Христовуљь краљиие Јелене, Историјска грађа, Записи, XI/1938, књ. ХIX, 111.

55 Филип Радичевић, Бураћ Стратимировић (Балшић) дарива неке земье манастиру Врањини, Просвјета, 1/1889, бр. Х, 337.

${ }^{56}$ Иларион Руварац, Камичцุи - прилошичи за други зетски дом, Просвјета 2/1893, св. ХII, 654-655.

${ }^{57}$ И. Руварац, Морачник, св. IX, 479.

${ }^{58}$ И. Руварац, Камичцุи - прилошщчи за други зетски дом, св. IX, 475-478.

${ }^{59}$ Исто, 475.

${ }^{60}$ Исто, 477.

${ }^{61}$ И. Руварац, Манастир св. Николе на Врањини у скадарском блату, св. XI, 538.

${ }^{62}$ Ф. Радичевић, Успенски манастир на Кому, 210.

63 Андрија Јовићевић, Манастир Врањина, Древни српски манастири, Никшић 2011, 30. (= Зетски гласник, V/1933, бр. 64, 2; бр. 65, 2; бр. 66, 2)
} 
тетроеванђелије, стари рукопис са записом: „сіе еvангеліе старчеве горице“, и у Споменику CKА III помиње се на страни 211, на крају неки пролог, у ком има запис, гдје се каже да је пролог написан у Горици Светог старца Макарија за вријеме владавине благочастивог господина Ђурђа Балшића. ${ }^{64}$

Иларион Руварац наводи да се у једном тетројеванђељу, које се налази у Русији и које је Рус А. Кочубински описао у Јагићевом Архиву за словенску филологију (књ. Х, стр. 580-585), налази запис из којег се сазнаје да је ту књигу писао и дописао јеромонах Мина, године 6944, мјесеца марта (1436) и да је књига написана у вријеме господина деспота Ђурђа (Бранковића), трудом и настојањем и трошком игумана Врањинског манастира Романа. Руварац доноси и текст записа. ${ }^{65}$

У извјештају Михалака Камбалура о српским црквама у Скадру и околини наводи се да је у вароши Скадру, мјесто џамије „Табаку“, близу тврђаве скадарске била стара Црква Св. Павла; зграда „Бурутхане“ близу моста „Бакчелико“ испод тврђаве, у којој се налази барутана била је стари манастир Св. Јована, Војна тамница у тврђави била је некад стара Црква Св. Марије. Најинтересантнији податак је да се у околини, у Цркви Св. Сергија (у рушевинама) близу Обота, села на Бојани, налази гроб српског краља Душана и његове супруге, краљице Јелене. ${ }^{66}$

Велики број текстова у црногорској периодици од 1835. до 1941. године у којима су обрађени манастири у Скадарском басену гововори о великој улози и значају који је имала Српска православна црква на овом подручју током средњег вијека као и на сачувану традицију о величини и моћи српске средњовјековне државе.

\footnotetext{
${ }^{64}$ И. Руварац, Старчева Горица, бр. IX, 479.

${ }^{65}$ И. Руварац, Камичцฺи - прилошии за други зетски дом, св. ХІІ, 651.

${ }^{66}$ Михалаки Камбалури, Извјештај Михалака Камбалура о српским ирквама у Скадру и околини 12. септембар 1915, Историјска грађа, Записи, ХII/ 1939, књ. ХХІ, 309-310.
} 


\title{
MEDIEVAL MONASTERIES IN THE BASIN OF LAKE SKADAR IN THE PERIODICALS PUBLISHED IN THE TERRITORY OF MONTENEGRO FROM 1835 TO 1941
}

\begin{abstract}
Summary
This paper analyses the articles in periodicals published in the territory of Montenegro from 1835 to 1941, which describe the monasteries in the basin of Lake Skadar. During the Middle Ages the Lake and its surroundings geographically belonged to Duklja, Zeta and was part of the states that left rich cultural legacy. Serbian ruling dynasties the Vojislavljević, Nemanjić, Balšić and Crnojević built monasteries in basin of the lake and bestowed on them rich gifts, such as Prečista Krajinska, Vranjina, Beška, Starčevo, Moračnik, and Kom. Filip Radičević, Ilarion Ruvarac, Andrija Jovićević, Marko Dragovic, Lazar Tomanović, Toma Oraovac et al. wrote about these monasteries in Montenegrin periodicals. A large number of these articles spoke about the great role and influence of the Serbian Orthodox Church in this area during the Middle Ages, thus saving the tradition about the size and power of Serbian medieval state.
\end{abstract}

Keywords: Skadar Basin, monasteries, periodicals, charters, Montenegro. 